\title{
Effects of Prenatal Electronic Cigarette Exposure On Foetal Development: a Review of the Literature
}

\section{Einfluss pränataler E-Zigaretten-Exposition auf die fetale Entwicklung: ein Überblick}

\section{(우(1) (오 $\ominus$}

\author{
Authors \\ Pia Römer, Amanda Goméz Putzer, Robin Kemmerich, Birgit Mathes
}

Affiliation

Bremer Initiative to Foster Early Child Development, Department 11, University of Bremen, Germany

Key words

E-cigarette, pregnancy, foetal development, prevention

Schlüsselwörter

E-Zigarette, Schwangerschaft, fetale Entwicklung, Prävention

received

accepted after revision

8.6. 2021

Bibliography

Geburtsh Frauenheilk 2021; 81: 1224-1237

DOI 10.1055/a-1524-5155

ISSN 0016-5751

(c) 2021. The Author(s).

This is an open access article published by Thieme under the terms of the Creative Commons Attribution-NonDerivative-NonCommercial-License, permitting copying and reproduction so long as the original work is given appropriate credit. Contents may not be used for commercial purposes, or adapted, remixed, transformed or built upon. (https://creativecommons.org/licenses/by-nc-nd/4.0/)

Georg Thieme Verlag KG, Rüdigerstraße 14,

70469 Stuttgart, Germany

Correspondence

Pia Römer

University of Bremen, Bremer Initiative to Foster

Early Child Development, Department 11

Mary-Somerville-Straße 3, 28359 Bremen, Germany

proemer@uni-bremen.de

$\oplus$

Deutsche Version unter:

https://doi.org/10.1055/a-1524-5155

Supplementary material is available under

https://doi.org/10.1055/a-1524-5155

\section{ABSTRACT}

Since their market launch in 2007, e-cigarettes gained popularity and were considered a relatively safe alternative to traditional cigarettes. Pregnant women and women of childbear- ing age in particular are increasingly turning to e-cigarettes. Little is known about the effects of prenatal exposure on the affected foetus. This paper aims to provide an overview of the current research on the effects of prenatal e-cigarette exposure on the foetus. Since studies in humans are lacking to date, this review refers only to animal and in vitro analyses. The PubMed and Web of Science databases were used for an extensive literature search. The search yielded $N=17$ significant research papers. Possible sequelae resulting from prenatal exposure to traditional cigarettes were also seen in prenatal exposure to e-cigarettes. Prenatal e-cigarette exposure was found to be associated with increased DNA methylation overall, resulting in lower gene expression. This could adversely impact the development of affected children, especially in case of those genes relevant to their development. In mice, for example, this greatly reduced the cell vitality of neural and stem cells and increased cell death. Further, prenatal exposure to e-cigarettes resulted in numerous developmental disorders, such as malformations of facial morphology and lower birth weight. Moreover, in animal models the animals suffered from a deterioration of their short-term memory. Activity and cognitive flexibility increased, while anxiety behaviour decreased. It is clear that more research and especially studies of humans are needed on this issue. In addition, there is a need for more intense education of prenatal care professionals as well as women of childbearing age and during pregnancy.

\section{ZUSAMMENFASSUNG}

Seit der Markteinführung im Jahr 2007 gewannen E-Zigaretten an Popularität und galten als vergleichsweise sichere Alternative zu konventionellen Zigaretten. Insbesondere bei Schwangeren und bei Frauen im gebärfähigen Alter werden vermehrt E-Zigaretten konsumiert. Zu Auswirkungen pränataler Exposition auf den betroffenen Fetus ist bisher wenig bekannt. Das Ziel ist es, eine Übersicht zur aktuellen Forschungslage zum Thema Auswirkungen pränataler E-Zigaretten-Exposition auf den Fetus zu geben. Aufgrund bisher fehlender Humanstudien bezieht sich diese Übersicht ausschließlich auf Tier- und In-vitro-Analysen. Für eine umfangreiche Literatur- 
recherche wurden die Datenbanken PubMed und Web of Science verwendet. Die Recherche resultierte in $\mathrm{N}=17$ relevanten Forschungsarbeiten. Folgeschäden, die durch die pränatale Exposition konventioneller Zigaretten entstehen können, zeigten sich auch bei pränataler E-Zigaretten-Exposition. Es konnte eine Assoziation zwischen pränataler E-Zigaretten-Exposition und einer global gesteigerten DNA-Methylierung festgestellt werden, was in einer geringeren Genexpression resultiert. Dies könnte besonders bei entwicklungsrelevanten Genen zu negativen Folgen für entsprechende Entwicklungsbereiche betroffener Kinder führen. So kam es bei Mäusen zu einer stark verminderten Zellvitalität von neuronalen und
Stammzellen und zu vermehrtem Zelltod. Weiter führte die pränatale Exposition von E-Zigaretten zu einer Vielzahl von Entwicklungsstörungen, wie Fehlbildungen der Gesichtsmorphologie oder geringeres Geburtsgewicht. Zudem konnte im Tierexperiment eine Verschlechterung des Kurzzeitgedächtnisses bei den Tieren festgestellt werden. Aktivität und kognitive Flexibilität waren gesteigert, Angstverhalten vermindert. Es wird deutlich, dass mehr Forschungsarbeiten und insbesondere Humanstudien zu diesem Thema benötigt werden. Zudem bedarf es einer intensiveren Aufklärung des Fachpersonals der Schwangerschaftsbetreuung sowie der Frauen im gebärfähigen Alter und während der Schwangerschaft.

\section{Abbreviations}

$\begin{array}{ll}\mathrm{CDC} & \text { Centers for Disease Control and Prevention } \\ \mathrm{CH}_{3} & \text { Methyl group } \\ \mathrm{CNS} & \text { Central Nervous System } \\ \text { DNA } & \text { Deoxyribonucleic Acid } \\ \text { e-cigarette } & \text { electronic cigarette } \\ \text { E-Liquid } & \text { Electronic Liquid } \\ \text { ENDS } & \text { Electronic Nicotine Delivery Systems } \\ \text { Iba-1 } & \text { Ionized Calcium-binding-Adapter Molecule 1 } \\ \text { IFN-gamma } & \text { Interferon-gamma } \\ \text { IL } & \text { Interleukin } \\ \text { NHS } & \text { National Health Service } \\ + \text { Nic } & \text { Nicotine-containing } \\ \text {-Nic } & \text { Nicotine-less } \\ \text { NPY } & \text { Neuropeptide Y } \\ \text { SIMH } & \text { Stress-Induced Mitochondrial Hyperfusion } \\ \text { TNF-alpha } & \text { Tumour necrosis factor alpha } \\ \text { WHO } & \text { World Health Organization }\end{array}$

\section{Introduction}

Patented by the Chinese pharmacist Hon Lik, the electronic cigarette (e-cigarette) has been commercially available since 2007 [1]. It is a battery-powered device for heating and vaporising a liquid, usually containing nicotine, so that it can be inhaled by the consumer. Other additives may include flavours and substrates [2]. The consequences of prenatal e-cigarette exposure have not yet been adequately studied. Since the current literature is primarily lacking in human studies, the effects on human offspring are still unknown.

In comparison, the effects of traditional cigarettes include miscarriages, stillbirths, later-onset respiratory disorders, cardiovascular diseases, and behavioural problems, all of which are documented and known from human studies [3]. To reduce these sequelae, e-cigarettes were originally designed as a transitional solution and replacement product to facilitate the process of quitting traditional cigarettes [1].

About 14\% of 2020 European Union citizens surveyed have tried e-cigarettes at least once in their lives. A total of $2 \%$ consumed e-cigarettes on a regular basis. The use of e-cigarettes, especially among the young generation, appears to be on the rise
[4]. In comparison, $22 \%$ of citizens have already smoked traditional cigarettes in their lifetime, while $23 \%$ are smoking them regularly. The mean number of cigarettes consumed, on the other hand, increases with age [4]. Most female e-cigarette users are of childbearing age [5]. Current international studies estimate the prevalence of e-cigarette use during pregnancy at 0.5-15\% [68]. Pregnant women justify their e-cigarette vaping by their intention to stop smoking traditional cigarettes. However, this effect cannot be demonstrated [9].

In comparison, the prevalence of traditional cigarette use during pregnancy is estimated at $1.7 \%$ overall [10]. Based on the increasing use of e-cigarettes among the young, it is reasonable to assume that the number of users will continue to rise [4].

Still, medical screening during pregnancy is less likely to include questions on e-cigarettes vaping than on the use of traditional cigarettes. In addition, public advertising campaigns promote its consumption. This not only prevents optimal prevention for substance reduction, but also contributes to the social perception that e-cigarettes are safer [8]. In line with this, analyses of online forums, especially for pregnant women, also showed that most users were aware of the risks and generally had a good understanding of how e-cigarettes worked, but that on the whole e-cigarettes were considered safer than traditional cigarettes [5, 11]. The UK National Health Service currently recommends that smokers switch to e-cigarettes during pregnancy. This is justified by the absence of tar and carbon dioxide as teratogenic substances when using e-cigarettes rather than traditional cigarettes [12]. However, this concept is controversial among experts both in Germany and worldwide. Previous trials regarded e-cigarette vaping during pregnancy as particularly dangerous because the foetus absorbs not only the nicotine but also heavy metals and potentially harmful chemicals through the maternal bloodstream [13]. Just as with the consumption of traditional cigarettes, the inhaled substances directly impact the foetus via the placenta [14]. Internationally recognised institutions for the promotion of public health, including the World Health Organization (WHO), therefore speak out against the use of e-cigarettes during pregnancy [15]. As e-cigarettes are a relatively new product, the effects of their use during pregnancy on the unborn child are insufficiently studied. Previous reviews highlighted the need for human studies to generate results that represent the precise sequelae of prenatal e-cigarette exposure [7,16-18]. The increasing number of users 
also shows that a better understanding of the effects of e-cigarettes on human foetal development is still needed and important in order to better inform pregnant women and assess the risks for the affected foetuses. The following paper provides a review of the effects of prenatal e-cigarette exposure on foetal and postnatal development based on animal models. This presents the current state of research, keeps this issue in focus and once again draws attention to the lack of human trials.

\section{Summary}

\section{Method}

\section{Literature search strategy}

The literature search on the effects of prenatal e-cigarette exposure on foetal development was conducted in the PubMed and Web of Science meta-databases. These databases were chosen for their broad range of publications with high scientific significance as well as their focus on medical and biological content. The search was conducted in June 2020 and updated in November 2020. Since most of the publications on this topic are in English, the search used only English search terms.

The inclusion criteria covered empirical research papers published between January 2010 and November 2020. Reviews and studies published before 2010 were excluded. Since the market launch of e-cigarettes has been dated to 2007, publications before 2010 do not reflect the operation of modern devices and are therefore of little value for this paper. Moreover, in order to generate a comprehensive overview, a period of 10 years was chosen.

The search used a combination of the following four keyword categories (A-D): A: Pregnancy, maternal, prenatal, offspring, foetal. B: E-cigarette, electronic cigarette, e-vapour, aerosol, electronic nicotine delivery systems, ENDS. C: Consumption, exposure. D: Development, effects, impact, growth, neurological, brain, cognitive, pulmonary, lung, respiratory. Following the literature search and elimination of duplicates, the titles and abstracts of all papers found were read first. Those papers were then excluded that were obviously irrelevant to the current topic. The full texts of the remaining papers were then reviewed.

\section{Data extraction}

A total of 17 studies were identified that investigated the effects of prenatal e-cigarette exposure on the foetus. The details of each studies were extracted by one author (AGP) and then verified for accuracy and completeness by another author (PR). Any minor discrepancies were discussed and resolved among the authors. - Tables 1 to $\mathbf{4}$ summarise the relevant data from each study. All four tables provide information on the following aspects of the studies included: Authors; year of publication and region where the research was conducted; type of study in terms of model organisms (e.g. animals); total number (N) of organisms studied; active substance of the exposure; as well as the duration of exposure; measurement timing studied; outcomes measured; and main conclusions.

\section{Assessing the quality and risk of bias}

Quality and bias assessment for all 17 studies according to the "OHAT Risk of Bias Rating Tool for Human and Animal Studies" [19] is summarised in Table S1. This tool was developed based on the latest Agency for Healthcare Research and Quality guidelines [20] and applied to each study included in this review. It was used to assess aspects such as randomisation, blinding and selective reporting of results (Table S1). The studies were assessed on a fourpoint scale based on eight questions: "Definitely low risk of bias", "Probably low risk of bias", "Probably high risk of bias", "Definitely high risk of bias". The assessment was carried out by one author (RK) and then verified for accuracy and completeness by another author (PR). Below, the terms "+Nic" and "-Nic" are used to indicate whether the administered exposure medium contained nicotine $(+\mathrm{Nic})$ or not $(-\mathrm{Nic})$. The designation of $+/-\mathrm{Nic}$ comprises both groups. These designations were made irrespective of possible other additives, the effects of which could be studied depending on $+/$-Nic. The control groups were animals exposed to room air that did not inhale any of the e-cigarette ingredients. In general, exposure of e-cigarettes and their ingredients in the studies included in this review was carried out via various specially designed boxes housing the laboratory animals (see e.g.: $[12,13]$ ).

Due to the lack of studies in humans, this review only includes findings based on animal experiments.

\section{Outcomes}

In the course of the literature search, it was discovered that research on the effects of prenatal e-cigarette exposure on foetal development had so far been conducted solely at the level of animal experiments. Most of the studies included $(N=17)$ focused their research on neurobiological ( $n=8$ studies, $>$ Table 1 ) and on respiratory effects and other organ systems ( $n=8$, - Table 2 ). The latter include studies on pulmonary ( $n=4$ studies), cardiovascular ( $n=2$ studies), facial morphology ( $n=1$ study), and renal sequelae ( $n=1$ study). Some of the 17 studies also reported findings on various birth parameters ( $\mathrm{n}=12$ studies, $>$ Table 3 ) and effects on cognition and behaviour ( $n=5$ studies, $>$ Table 4 ).

The studies included in this review were of adequate overall quality and the risk of bias was low. In 10 of the 17 studies, it can definitely be assumed that prenatal exposure was adequately randomised, while in six studies such adequate randomisation was probable. Only one study demonstrated a probable high risk of bias in this respect, which had to be taken into account when interpreting the outcomes. In terms of identical experimental conditions in all study groups, the risk of bias was definitely low in $\mathrm{n}=14$ studies and probably low in three studies. All 17 studies were assessed as having a definitely low risk of bias with regard to the appropriate reporting of the outcomes. Other aspects and more detailed information can be found in Table S1. Differences in study quality and risk of bias can be explained, for example, by differences in study design and different survey methodology.

\section{Neurobiological markers}

The publications on the effects on neurobiological markers listed in $>$ Table 1 concern neural cell vitality, neuroepigenetic changes, neuroinflammation, and neurometabolism. 
- Table 1 Animal studies on the effects of prenatal e-cigarette exposure on neurobiological markers.

\begin{tabular}{|c|c|c|c|c|c|c|c|}
\hline $\begin{array}{l}\text { Author, } \\
\text { year } \\
\text { (region) }\end{array}$ & $\begin{array}{l}\text { Study } \\
\text { type }\end{array}$ & N & $\begin{array}{l}\text { Active } \\
\text { substance }\end{array}$ & Period of exposure & $\begin{array}{l}\text { Measurement } \\
\text { timing }\end{array}$ & Measurements & Outcomes \\
\hline $\begin{array}{l}\text { Zahedi } \\
\text { et al., } 2019 \\
\text { (USA) }\end{array}$ & In vitro & $\begin{array}{l}48000 \\
\text { neural } \\
\text { stem cells }\end{array}$ & $\begin{array}{l}\text { E-cigarette } \\
\text { liquids with } \\
\text { tobacco and } \\
\text { menthol } \\
\text { flavour with } \\
\text { nicotine }\end{array}$ & $\begin{array}{l}\text { Mouse cells were } \\
\text { exposed to the } \\
\text { aerosol for 2-24 } \\
\text { hours }\end{array}$ & n.s. & $\begin{array}{l}\text { Mitochondrial } \\
\text { adaptation reac- } \\
\text { tions in response } \\
\text { to oxidative stress }\end{array}$ & $\begin{array}{l}\text { Cellular stress due to } \\
\text { e-cigarette exposure }\end{array}$ \\
\hline $\begin{array}{l}\text { Sifat et al., } \\
2020 \text { (USA) }\end{array}$ & $\begin{array}{l}\text { Animal } \\
\text { study } \\
\text { (mice) }\end{array}$ & 121 pups & $\begin{array}{l}\text { E-liquid with } \\
24 \mathrm{mg} / \mathrm{mL} \\
\text { nicotine }\end{array}$ & DP 5 to PN day 7 & $\begin{array}{l}\text { PN day } 8-9 \text { and } \\
40-45\end{array}$ & $\begin{array}{l}\text { Effects on cortical } \\
\text { cells }\end{array}$ & $\begin{array}{l}\text { Reduced cellular vitality. } \\
\text { Deterioration in memo- } \\
\text { ry, learning, motor } \\
\text { coordination. }\end{array}$ \\
\hline $\begin{array}{l}\text { Zelikoff } \\
\text { et al., } 2017 \\
\text { (USA) }\end{array}$ & $\begin{array}{l}\text { Animal } \\
\text { study } \\
\text { (mice) }\end{array}$ & n.s. & $\begin{array}{l}\text { E-liquid with } \\
\text { tobacco and } \\
\text { menthol fla- } \\
\text { vours and with- } \\
\text { out nicotine } \\
(13 \mathrm{mg} / \mathrm{mL})\end{array}$ & $\begin{array}{l}6 \text { weeks before } \\
\text { fertilisation until PN } \\
\text { day } 20\end{array}$ & PN day 28 & $\begin{array}{l}\text { Effects on cells of } \\
\text { the hippocampal } \\
\text { region }\end{array}$ & $\begin{array}{l}\text { Reduced cellular vitality } \\
\text { and increased inflam- } \\
\text { mation }\end{array}$ \\
\hline $\begin{array}{l}\text { Nguyen } \\
\text { et al., } 2018 \\
\text { (Australia) }\end{array}$ & $\begin{array}{l}\text { Animal } \\
\text { study } \\
\text { (mice) }\end{array}$ & 24 mothers & $\begin{array}{l}\text { E-liquid with } \\
\text { and without } \\
\text { nicotine } \\
(18 \mathrm{mg} / \mathrm{mL})\end{array}$ & $\begin{array}{l}6 \text { weeks before } \\
\text { fertilisation until PN } \\
\text { day } 20\end{array}$ & $\begin{array}{l}\text { PN day } 1,20 \\
\text { and } 84\end{array}$ & $\begin{array}{l}\text { Neuroepigenetic } \\
\text { and cognitive } \\
\text { changes }\end{array}$ & $\begin{array}{l}\text { Increased DNA } \\
\text { methylation }\end{array}$ \\
\hline $\begin{array}{l}\text { Nguyen } \\
\text { et al., } 2019 \\
\text { (Australia) }\end{array}$ & $\begin{array}{l}\text { Animal } \\
\text { study } \\
\text { (mice) }\end{array}$ & 24 mothers & $\begin{array}{l}\text { Tobacco- } \\
\text { flavoured } \\
\text { e-liquid with } \\
18 \mathrm{mg} / \mathrm{mL} \\
\text { nicotine }\end{array}$ & $\begin{array}{l}\text { Group A: TC9 weeks } \\
\text { before fertilisation, } \\
\text { e-liquid until PN } \\
\text { day } 20 \\
\text { Group B: E-liquid } \\
\text { fertilisation until PN } \\
\text { day } 20\end{array}$ & $\begin{array}{l}\text { PN day } 1,20,84 \\
\text { and } 91\end{array}$ & $\begin{array}{l}\text { Neuroepigenetic } \\
\text { changes and ef- } \\
\text { fects on memory } \\
\text { and behaviour }\end{array}$ & $\begin{array}{l}\text { Altered gene expression } \\
\text { and restricted STM. } \\
\text { Increased exploration } \\
\text { behaviour }\end{array}$ \\
\hline $\begin{array}{l}\text { Lauterstein } \\
\text { et al., } 2016 \\
\text { (USA) }\end{array}$ & $\begin{array}{l}\text { Animal } \\
\text { study } \\
\text { (mice) }\end{array}$ & $\begin{array}{l}36 \text { young } \\
\text { animals }\end{array}$ & $\begin{array}{l}\text { E-liquid with } \\
\text { and without } \\
\text { nicotine (13- } \\
16 \mathrm{mg} / \mathrm{mL})\end{array}$ & $\begin{array}{l}\text { Fertilisation to PN } \\
\text { day } 25-27\end{array}$ & PN day 25-31 & $\begin{array}{l}\text { Effects on cells of } \\
\text { the frontal cortex }\end{array}$ & $\begin{array}{l}\text { Transcriptome alteration } \\
\text { in the frontal cortex }\end{array}$ \\
\hline $\begin{array}{l}\text { Church } \\
\text { et al., } 2020 \\
\text { (USA) }\end{array}$ & $\begin{array}{l}\text { Animal } \\
\text { study } \\
\text { (mice) }\end{array}$ & $\begin{array}{l}135 \text { young } \\
\text { animals }\end{array}$ & $\begin{array}{l}\text { E-liquid with } \\
\text { and without } \\
\text { nicotine } \\
(16 \mathrm{mg} / \mathrm{mL})\end{array}$ & $\begin{array}{l}\text { Fertilisation to DP } \\
17\end{array}$ & $\begin{array}{l}\text { PN day 21, } 56 \\
\text { and } 84\end{array}$ & $\begin{array}{l}\text { Effects on neuro- } \\
\text { inflammation and } \\
\text { cognition }\end{array}$ & $\begin{array}{l}\text { Elevated inflammation } \\
\text { parameters in some } \\
\text { brain regions as well as } \\
\text { changes in cognitive } \\
\text { abilities }\end{array}$ \\
\hline $\begin{array}{l}\text { Chen et al., } \\
2018 \\
\text { (Australia) }\end{array}$ & $\begin{array}{l}\text { Animal } \\
\text { study } \\
\text { (mice) }\end{array}$ & 8 mothers & $\begin{array}{l}\text { Tobacco } \\
\text { flavoured } \\
\text { e-liquid with } \\
\text { and without } \\
\text { nicotine } \\
(18 \mathrm{mg} / \mathrm{mL})\end{array}$ & $\begin{array}{l}6 \text { weeks before } \\
\text { fertilisation until PN } \\
\text { day } 20\end{array}$ & PN day 20 & $\begin{array}{l}\text { Effects on neuro- } \\
\text { inflammation and } \\
\text { neurometabolism }\end{array}$ & $\begin{array}{l}\text { Elevated inflammation } \\
\text { parameters and in- } \\
\text { creased metabolic } \\
\text { processes }\end{array}$ \\
\hline
\end{tabular}

PN = postnatal; DP = day of pregnancy; TC = traditional cigarette; DNA = Deoxyribonucleic acid; STM = short-term memory; n. s. = not specified

The in vitro studies by Zahedi et al. (2019) exposed neural stem cells from mice to the +Nic aerosol from e-cigarettes with different flavours for 24 hours. Stem cells can develop into any cell type [24] and are elementary for the regeneration and repair of tissues, organ formation and maintaining homoeostasis [23]. Neural stem cells have been shown to be sensitive to toxic substances, such as nicotine. They are therefore well suited for testing the safety of substances such as e-liquids [23]. Nicotine-containing aerosols elicit stress-induced mitochondrial hyperfusion (SIMH [23]). In this process, the mitochondria of the neural stem cells swell and fuse into long filamentous mitochondria. The high nicotine level increasingly opens up ion channels in the membrane of neural stem cells, allowing calcium and other ions to flood the cells in large quantities. The high intracellular calcium level results in a calcium influx into the mitochondria. Too much calcium has a toxic effect on the mitochondria. SIMH may be regarded as a protective mechanism in response to the cellular stress induced by high nicotine levels [25]. Furthermore, the experiment by Zahedi et al. also caused mitochondrial oxidative stress [23]. Oxidative stress can also lead to breaks in deoxyribonucleic acid (DNA) 
strands, inactivation of enzymes and damage to vulnerable nerve cells [26]. Mitochondrial matrix proteins are particularly susceptible to oxidative stress. Their reaction has negative effects on the respiratory chain and therefore the findings suggest the risk of energy deficiency in foetuses whose mothers vape e-cigarettes [27]. Moreover, the study by Zahedi et al. (2019) demonstrated that nicotine causes intracellular calcium excess, which may result in serious sequelae such as rupture of cell membranes [23]. The effects of e-liquid aerosols on neural stem cells therefore appear to be triggered by the nicotine and not by the flavours or substrates of the e-liquid [23]. Sifat et al. (2019) studied the effects of +Nic e-cigarette aerosols on cortical cells in mice. An altogether decreased neuronal metabolism was noted. This became evident by a reduction in glucose uptake, expression of glucose transporters, adenosine triphosphate content, as well as a lower mitochondrial membrane potential [22]. E-cigarette exposure also led to reduced cell viability and increased DNA damage [22]. In addition, the researchers found increased sensitivity of the mice to postnatal hypoxic-ischaemic brain injury caused by prenatal exposure to +Nic e-cigarettes, which is also seen in neonates with inadequate oxygen supply. Effects on cellular vitality were also observed in the hippocampus. Certain nerve growth factors were decreased after prenatal +Nic as well as -Nic e-cigarette use. This may cause growth disorders and impair hippocampal function [22]. This was accompanied by an increase in long-term deficits, spatial acquisition and reference memory [22]. Epigenetics describes modifications of gene activity that arise, for example, through environmental effects such as the consumption of toxic substances and may lead to a change in phenotype [28]. DNA methylation is an epigenetic mechanism in which DNA methyltransferases add a methyl group $(\mathrm{CH} 3)$ to the cytosine base of a DNA nucleotide. Methylated cytosines inactivate the gene. Looking at neuronal development, DNA methylation affects when which genes are expressed or silenced. For example, increased methylation may lead to the non-expression of certain genes, thereby affecting brain development [28]. In mice, it could be shown that prenatal +/-Nic cigarette exposure temporarily led to significantly increased DNA methylation in the brain cells [29]. Compared with exposure to traditional cigarette smoke, however, the degree of DNA methylation was significantly lower in mice whose intrauterine exposure was changed from cigarette smoke to +Nic e-cigarettes. It appears that DNA methylation correlates strongly with exposure to traditional cigarette smoke [21]. In addition, the expression of the genes coding for the enzymes regulating DNA methylation was also studied. It was noted that under the influence of -Nic e-cigarettes, these genes exhibited a pattern of variance compared to the control group that was greater than that compared to +Nic e-cigarettes [29]. The varying gene expression also affected genes coding for mitotic kinases, which play an important role in cell growth. In these two cases, the variance was also smaller than in traditional nicotine exposure [21]. Another approach to the epigenetic effects of e-cigarettes is transcriptome analysis. The transcriptome is the set of all genes transcribed in the cell at a given time [28]. Transcription is an important subprocess of gene expression that determines the effect of the genome on the phenotype. Lauterstein et al. (2016) used a mouse model to demonstrate that both $+\mathrm{Nic}$ and $-\mathrm{Nic}$ prenatal e-cigarette aerosol exposure causes changes in the central nervous system (CNS) transcriptome. Compared to mice in the control group, which only inhaled air, this primarily affected cells of the frontal cortex [30]. With the help of databases, it is possible to compare the gene changes with gene profiles correlating with individual diseases, developmental disorders and general functional impairments. This analysis showed that the above changes can probably result in reduced memory, cognition, and learning ability as well as poorer neurotransmission. Moreover, correlations between aerosol exposure and increased hyperactivity, increased emotionality and seizures were observed post partum. The altered CNS transcriptome was also linked to neuronal growth disorders. Particularly striking here were impairments in dendrite growth and neuron density and also increased cell death [30].

Neuroinflammation is the inflammation of nerve tissue. This usually describes chronic inflammation of the CNS. Inflammation arises as an immune response to a harmful stimulus, with the aim of eliminating it. At the molecular level, so-called inflammatory mediators play a major role in inflammatory reactions. They can initiate, amplify and maintain inflammatory processes to counteract a harmful stimulus such as e-cigarette aerosols or nicotine. They therefore have a proinflammatory effect [31]. Depending on the situation, inflammatory processes may have a variety of psychological, immunological, physiological or biochemical consequences [31]. Individual changes in inflammatory mediators have been detected in the hippocampus and the diencephalon as a result of prenatal exposure to $+\mathrm{Nic}$ e-cigarettes [32]. Compared to the control group, a decrease in the level of interferon-gamma (IFN-gamma) in the hippocampus of female offspring was observed. Moreover, in offspring of both sexes a decrease in IFNgamma and the cytokine of the interleukin family IL-4 was observed in their diencephalon [32]. This reduction in immune signalling is thought to be due to the well-documented immunosuppressive effects of nicotine on the central nervous system [33]. In addition, this may reflect the ability of nicotine to inhibit the maturation and function of $\mathrm{T}$ lymphocytes through activation of the acetylcholine receptor. T cells are special lymphocytes that play an important role in the induction of the immune response, with their differentiation also being induced by IL-4 cytokines [32]. An increase in the so-called "ionised calcium-binding adapter molecule 1" (Iba-1) was also observed in the hippocampus and frontal cortex for the group of prenatal -Nic e-cigarette exposure [34]. This is a protein that is upregulated after nerve injury, neuronal ischaemia and brain injury. It was considered noteworthy that the reduction in Iba- 1 only applied to the -Nic group. This implied that there were elevated levels of inflammation in the -Nic group, which could damage neuronal development further down the line [34]. Irrespective of the region, it was found that prenatal exposure to -Nic e-cigarettes increased the concentration of inducible nitric oxide synthase (NO synthase) in affected offspring. Elevated NO synthase levels can lead to dysregulation of brain regulatory pathways through oxidative stress, which may result in CNS damage [35].

One aspect often associated with tobacco use is inhibited appetite. Children with prenatal exposure to tobacco had an increased likelihood of developing obesity during childhood, which might be attributed to the effects of tobacco withdrawal [36]. 
- Table 2 Animal studies on the effects of prenatal e-cigarette exposure on the lungs and other organ systems.

\begin{tabular}{|c|c|c|c|c|c|c|c|}
\hline $\begin{array}{l}\text { Author, } \\
\text { year } \\
\text { (region) }\end{array}$ & $\begin{array}{l}\text { Study } \\
\text { type }\end{array}$ & N & $\begin{array}{l}\text { Active } \\
\text { substance }\end{array}$ & Period of exposure & $\begin{array}{l}\text { Measurement } \\
\text { timing }\end{array}$ & Measurements & Outcomes \\
\hline $\begin{array}{l}\text { Nöel et al., } \\
2020 \text { (USA) }\end{array}$ & $\begin{array}{l}\text { Animal } \\
\text { experi- } \\
\text { ments } \\
\text { (mice) }\end{array}$ & $\begin{array}{l}183 \text { young } \\
\text { animals }\end{array}$ & $\begin{array}{l}\text { Cinnamon- } \\
\text { flavoured } \\
\text { e-liquid with } \\
36 \mathrm{mg} / \mathrm{mL} \\
\text { nicotine }\end{array}$ & $\begin{array}{l}\text { Group A: } 12 \text { days } \\
\text { before fertilisation } \\
\text { until DP } 19 \\
\text { Group B: Fertilisa- } \\
\text { tion until DP } 19\end{array}$ & PN day 1 and 28 & $\begin{array}{l}\text { Effects on lung } \\
\text { tissue and func- } \\
\text { tion }\end{array}$ & $\begin{array}{l}\text { Changes in lung struc- } \\
\text { ture and dysregulation } \\
\text { of the Wnt signalling } \\
\text { pathway }\end{array}$ \\
\hline $\begin{array}{l}\text { Chen et al., } \\
2017 \\
\text { (Australia) }\end{array}$ & $\begin{array}{l}\text { Animal } \\
\text { experi- } \\
\text { ments } \\
\text { (mice) }\end{array}$ & n.s. & $\begin{array}{l}\text { E-liquid with } \\
\text { and without } \\
\text { nicotine } \\
(18 \mathrm{mg} / \mathrm{mL})\end{array}$ & $\begin{array}{l}6 \text { weeks before } \\
\text { fertilisation until PN } \\
\text { day } 20\end{array}$ & $\begin{array}{l}\text { PN day } 1,20 \\
\text { and } 91\end{array}$ & $\begin{array}{l}\text { Effects on epi- } \\
\text { genetic processes } \\
\text { in lung tissue }\end{array}$ & $\begin{array}{l}\text { Changes in DNA methyl- } \\
\text { ation and proinflamma- } \\
\text { tory cytokines in the } \\
\text { lung unrelated to } \\
\text { nicotine content }\end{array}$ \\
\hline $\begin{array}{l}\text { McAlinden } \\
\text { et al., } 2017 \\
\text { (Australia) }\end{array}$ & $\begin{array}{l}\text { Animal } \\
\text { experi- } \\
\text { ments } \\
\text { (mice) }\end{array}$ & n.s. & $\begin{array}{l}\text { Group A: } \\
\text { TC and +Nic } \\
\text { e-liquid; } \\
\text { Group B: } \\
\text { E-liquid with } \\
\text { and without } \\
\text { nicotine }\end{array}$ & $\begin{array}{l}\text { Group A: TC until } \\
\text { fertilisation, } \\
\text { e-liquid until birth } \\
\text { Group B: E-liquid } \\
\text { Fertilisation up to } \\
\text { PN1 }\end{array}$ & n.s. & $\begin{array}{l}\text { Effects on lung } \\
\text { tissue and func- } \\
\text { tion }\end{array}$ & $\begin{array}{l}\text { +Nic e-cigarettes exac- } \\
\text { erbate allergic asthma. }\end{array}$ \\
\hline $\begin{array}{l}\text { Berkel- } \\
\text { hammer } \\
\text { et al., } 2019 \\
\text { (USA) }\end{array}$ & In vitro & $\begin{array}{l}\text { Pulmonary } \\
\text { muscle cell } \\
\text { specimen }\end{array}$ & $\begin{array}{l}\text { Flavoured } \\
\text { e-liquids }\end{array}$ & Exposure $1 \mathrm{~h}$ & $\begin{array}{l}\text { After } 24 \mathrm{~h} \\
\text { incubation }\end{array}$ & $\begin{array}{l}\text { Effects on muscle } \\
\text { cells of the lung }\end{array}$ & $\begin{array}{l}\text { Neonatal cells exhibit } \\
\text { strong sensitivity } \\
\text { to e-liquid toxicity. } \\
\text { Flavours lead to in- } \\
\text { creased cell death. }\end{array}$ \\
\hline $\begin{array}{l}\text { Kennedy } \\
\text { et al., } 2017 \\
\text { (USA) }\end{array}$ & $\begin{array}{l}\text { Animal } \\
\text { study } \\
\text { (Xenopus } \\
\text { laevis) }\end{array}$ & n.s. & $\begin{array}{l}\text { E-liquid with } \\
\text { and without } \\
\text { flavour and } \\
\text { nicotine }\end{array}$ & $\begin{array}{l}\text { Period of embry- } \\
\text { onic development }\end{array}$ & PN day 1 & $\begin{array}{l}\text { Effects on facial } \\
\text { morphology }\end{array}$ & $\begin{array}{l}\text { E-liquid consumption } \\
\text { leads to craniofacial } \\
\text { deformation. This is } \\
\text { exacerbated by nicotine } \\
\text { and flavours. }\end{array}$ \\
\hline $\begin{array}{l}\text { Orbazal } \\
\text { et al., } 2019 \\
\text { (USA) }\end{array}$ & $\begin{array}{l}\text { Animal } \\
\text { study } \\
\text { (mice) }\end{array}$ & n.s. & $\begin{array}{l}\text { E-liquid with } \\
\text { and without } \\
\text { nicotine } \\
(100 \mathrm{mg} / \mathrm{mL})\end{array}$ & ST 5 - PN10 & PN day 10 & $\begin{array}{l}\text { Effects on birth } \\
\text { parameters }\end{array}$ & $\begin{array}{l}\text { +Nic e-liquid restricts } \\
\text { growth and decreases } \\
\text { the blood supply. }\end{array}$ \\
\hline $\begin{array}{l}\text { Palpant } \\
\text { et al., } 2015 \\
\text { (USA) }\end{array}$ & $\begin{array}{l}\text { Animal } \\
\text { study } \\
\text { (zebrafish) }\end{array}$ & n.s. & +Nic e-liquid & 3 days prenatal & $\begin{array}{l}\text { Following } \\
\text { the exposure }\end{array}$ & $\begin{array}{l}\text { Effects on the } \\
\text { cardiovascular } \\
\text { system }\end{array}$ & $\begin{array}{l}\text { Cardiac malformations, } \\
\text { impaired cardiac func- } \\
\text { tion and pericardial } \\
\text { effusions }\end{array}$ \\
\hline $\begin{array}{l}\text { Li et al., } \\
2019 \\
\text { (Australia) }\end{array}$ & $\begin{array}{l}\text { Animal } \\
\text { study } \\
\text { (mice) }\end{array}$ & 143 & $\begin{array}{l}\text { E-liquid with } \\
\text { and without } \\
\text { nicotine } \\
(18 \mathrm{mg} / \mathrm{mL})\end{array}$ & $\begin{array}{l}\text { Group A: E-liquid } \\
6 \text { weeks before } \\
\text { fertilisation until PN } \\
\text { day } 20 \\
\text { Group B: TC6 weeks } \\
\text { before fertilisation, } \\
\text { then e-liquid until } \\
\text { PN day } 20\end{array}$ & PN day 1 and 20 & $\begin{array}{l}\text { Effects on } \\
\text { the renal tissue }\end{array}$ & $\begin{array}{l}\text { Prolonged exposure } \\
\text { to e-liquid results in } \\
\text { oxidative stress, inflam- } \\
\text { mation and fibrosis in } \\
\text { kidney tissue, regardless } \\
\text { of nicotine content. }\end{array}$ \\
\hline
\end{tabular}

$\mathrm{PN}=$ postnatal day; $\mathrm{DP}=$ day of pregnancy; $\mathrm{TC}=$ traditional cigarettes; $n$. $\mathbf{s .}=$ not specified

One study investigated whether these outcomes might also be extrapolated to the consumption of e-cigarettes. In mice, an increased presence of neuropeptide Y (NPY) was observed following maternal exposure to -Nic e-liquid [35]. NPY is produced in the hypothalamus and is believed to stimulate the appetite. Elevated levels in affected offspring may thus lead to weight gain, possibly even to obesity. Vaping +Nic aerosols counteracted this effect. Compared to the test group that received -Nic aerosol, no postnatal changes in the hunger response pathways were observed in the offspring of the +Nic test group. In contrast, offspring exposed to prenatal -Nic aerosols exhibited obesity [35]. These results suggest that aerosols and their chemical constituents appear to affect cerebral metabolic processes. Exposure to -Nic e-cigarettes thus does appear to carry some risk.

\section{Lungs and other organ systems}

- Table 2 lists publications on the effects on the lungs and other organ systems. Four studies on the effects on the lungs were iden- 
tified. These addressed anatomical and functional effects, inflammatory processes and the epigenetics of lung tissue. Other effects include cardiovascular and renal outcomes and morphological facial changes.

One study demonstrated that physiological processes controlling lung development were downregulated in offspring of animals exposed to +Nic e-cigarettes before fertilisation and from fertilisation onwards [37]. It is known that this may lead to less differentiated development of the lungs and a higher proportion of connective tissue. This will lead to impaired pulmonary function [38]. Also, offspring of mothers exposed to +Nic e-cigarettes before fertilisation exhibited increased elasticity of the lungs compared to the control group. Changes in elasticity, and thus the increased elasticity observed here, make breathing more difficult and can lead to secondary lung disorders [37]. The outcomes of another study show that both +Nic and -Nic e-cigarette exposure elevates certain growth factors in the lung tissue of affected offspring and alters DNA methylation processes [39]. Morphometric analyses also revealed that in the neonatal lung prenatal +Nic e-cigarette exposure leads to increased tears of the lung tissue [37]. In vitro analyses of the effects of different flavoured E-liquids on foetal and neonatal lung cells in mice found that different flavours elicited widely varying cell responses. While the pure substrates did not affect the cells, the combination with menthol and strawberry flavouring resulted in increased cell death [40]. Menthol also caused dilation of the bronchi [40]. In animals and humans, bronchial dilation results in a more pleasant perception of breathing, thereby markedly delaying the perception of lung disease symptoms [41]. Bronchial dilation also increases the effect of passive smoking in neonates and infants in the vicinity of e-cigarette vapours. This leads to a higher concentration of flavours, substrates and possibly nicotine in young, still developing lungs [40].

Other findings showed evidence that several genes regulating inflammation were modified in young animals whose mothers were exposed to +Nic e-cigarettes both prenatally and before fertilisation [37]. These outcomes suggested an anti-inflammatory effect of +Nic e-cigarettes. Likewise, the outcomes also showed that exposure to +Nic e-cigarettes before fertilisation may also affect the offspring. These manifested at both the molecular and anatomical levels as down-regulated genes supporting lung function as well as an increase in lung tissue. This can lead to lung immaturity and later on to lung disorders [37]. The levels of certain proinflammatory cytokines are known to be elevated in patients with asthma and chronic obstructive pulmonary disease. These include interleukins $1 \beta, 3,4,5,6,13$, and tumour necrosis factoralpha (TNF-alpha [39]). Measurements immediately after birth revealed that after prenatal exposure to -Nic e-cigarettes young animals exhibited an increased expression of interleukins 5 and 13 as well as TNF-alpha [39], which could indicate an increased tendency to asthmatic disorders. In line with this, another study investigated the extent to which prenatal exposure to e-cigarettes triggers asthma [42]. Pups exposed pre- and postnatally to + -Nic e-cigarette aerosols were tested in an allergy exposure model for their pulmonary function and the degree of inflammatory response. A particularly strong sensitivity to allergens and an increased airway resistance were observed in the +Nic group. Both can trigger asthma symptoms. The same findings were obtained in pups whose mothers were exposed to conventional cigarettes before fertilisation and to +Nic e-cigarettes after fertilisation. Presumably this was caused by increased mitochondrial oxygen consumption. This indicates damaged mitochondria with resulting tissue death leading to increased fibrosis [42].

In the studies by Chen et al. (2017), DNA methylation was found to be three times higher on day one after birth in mice of the -Nic group than in the control group. The +Nic group also exhibited an increase in DNA methylation compared to the control group, but this was less pronounced than that of the -Nic group. This suggests a change in gene activity, although further studies must identify which genes are affected [39].

\section{Cardiovascular organ system}

Studies on the offspring of animals exposed to e-cigarette aerosols with or without nicotine from fertilisation to the end of lactation revealed no changes in heart rate. However, in the +Nic e-cigarettes group, decreased blood flow through two arteries supplying oxygenated blood to the foetus was noted [43]. In newborn zebrafish, prenatal +Nic e-liquid exposure induced severe cardiac malformations, impaired cardiac function and pericardial effusions [44]. The latter includes fluid accumulation in the pericardium reducing cardiac output [45]. Decreased expression of cardiac transcription factors was also found. This delayed the differentiation and development of the heart cells, which in turn may cause heart defects. The heart muscle cells also exhibited reduced expression of genes encoding muscle components [46]. This reduced the number of contractile units in the muscle. As a result, the myocardial cells can only develop to a limited extent and the heart muscle becomes less efficient [47].

\section{Renal organ system}

According to an analysis in mice, prenatal exposure to e-cigarettes led to a lower density of kidney corpuscles in affected offspring. This finding indicates that the kidney is less developed and renal functions, including filtering function, regulation of water, nutrient and electrolyte balance, and blood pressure, are impaired [48]. The oxidative stress level in renal cells was elevated only in pups whose mothers had been exposed to -Nic e-cigarettes [48]. In addition, all pups with prenatal exposure to e-cigarettes exhibited increased inflammation in the kidneys. Persistent inflammatory response leads to increasing scarring and fibrosis, i.e., the replacement of functional tissue with connective tissue. Despite the heightened expression at the gene level, however, no increased presence of connective tissue was observed overall. However, this only applies to pups and may be different at more advanced stages of development [48].

\section{Morphological facial changes}

One study analysed the effects of prenatal e-cigarette exposure on the craniofacial morphology of the African clawed frog (xenopus laevis). Pure e-liquids with different nicotine levels and six commercially available flavoured e-liquids with comparable nicotine levels were tested [49]. The analysis revealed that exposure of the pure e-liquid with all nicotine levels resulted in changes. Rounder mouths and more closely set eyes were observed. The 
changes were more pronounced in the group whose mothers were given the e-liquid with the highest nicotine level $(24 \mathrm{mg} /$ $\mathrm{mL}$ ) [49]. Four of the six commercially available liquids induced similar insignificant changes in facial morphology. However, two e-liquids resulted in significant changes such as protruding eyes, a narrower midface and a rounder, narrower mouth with a triangular upper lip. The significant differences cannot be explained by a higher nicotine level, since all six liquids had similar nicotine concentrations [49]. Exposure to these two -Nic liquids also resulted in marked facial deformation, albeit less than that caused by exposure to liquids with high nicotine levels [49].

\section{Birth parameters}

The effects of prenatal exposure to e-cigarettes on birth parameters such as birth weight and litter size of affected offspring are given below. Twelve of the total of 17 publications examined provided information on these parameters, which are listed in - Table 3.

Neither stillbirths nor increased infantile mortality were observed in 4 of the 17 studies analysed [21,22, 29,32,37]. This is true for maternal prenatal e-cigarette exposure from the time of conception as well as for exposure of both parents weeks before conception. In the +Nic e-liquid group of zebrafish, however, studies observed a reduced survival rate within the first 72 hours [46].

On several occasions, reduced birth weight has been associated with prenatal +Nic e-cigarette exposure [21, 22, 37, 43, 48]. In one study, maternal animals were exposed to traditional tobacco before birth [21]. The findings of Smith et al. (2015) speak against the hypothesis that birth weight is lowered primarily by a high nicotine level. In this study, prenatal exposure of +Nic and -Nic led to a reduction in birth weight, and this effect was even stronger for -Nic compared to +Nic [21]. However, weight measurements in adults uniformly showed that any birth weight differences will level out later in life $[21,22,32,39]$. In addition to body weight, the weight of the liver and kidneys was also measured. Measurement one day after birth did not reveal any differences in liver weight between the study groups. At 20 days of age, measurements showed that passive pre- and postnatal +Nic e-cigarette aerosol exposure correlated with higher liver weight, as a percentage of body weight. Compared to the control and +Nic e-liquid groups, adult offspring of the -Nic e-liquid group experienced a significant reduction in liver weight [35]. At no time did the prenatal exposure to +Nic e-cigarettes show any changes in renal weight [48].

Animal studies often examine the distribution of fat stores, as they provide information on signs of obesity [48]. Measurements at one day of age showed no differences in fat distribution between the study groups [50]. In 20-day-old mice prenatally assigned to the -Nic e-liquid group, measurements revealed increased abdominal fat [39]. In another study, the same study group demonstrated an increased amount of fatty tissue in the region of the epididymis [35]. In mice, the lateral region of the epididymis extends from the testis to the diaphragm [39]. Regardless of nicotine level, prenatal e-cigarette exposure was also associated with increased fat mass in the abdominal cavity. In adult animals, these findings return to normal, but an increase in intraab- dominal fat mass was observed in offspring prenatally exposed to +Nic or-Nic e-cigarettes [50].

In two studies, body length measurements on postnatal day one revealed a marked reduction in body size after prenatal exposure to +Nic e-cigarettes [39]. The findings of Nöel et al. (2020) did not identify marked differences after prenatal exposure from fertilisation as well as after twelve days prior to fertilisation.

\section{Cognition and behaviour}

The following section describes the effects of prenatal e-cigarette exposure on cognition and behaviour in affected offspring. Of the total of 17 studies analysed, 5 studies provided information on this. These are listed in $>$ Table 4.

Changes in short-term memory in mice can be measured by the novel object recognition test. Here, the test object is placed in a box with two identical blocks. After a familiarisation phase, one of the blocks is replaced by a block of different shape and colour. The time spent on exploring the new block is measured. The test is based on the assumption that limitations of short-term memory, whereby the old block is not remembered as known, result in both blocks being explored for the same length of time after the switch [35]. When tested, adolescent mice prenatally exposed to e-cigarette vapour exhibited significant deterioration in object recognition [22]. This was true for the + Nic and $-\mathrm{Nic}$ groups compared to the control group [22] and could be replicated in adult animals [32]. In addition, mice were studied that were exposed to traditional cigarettes until fertilisation and then further exposed to +Nic e-cigarettes from fertilisation onwards. A clearly limited object recognition in adulthood was observed here [29]. On open-field testing, which measures locomotor activity, one study found significantly higher activity in offspring prenatally exposed to +Nic e-cigarette vapour compared to the control group [22]. In terms of the translation to humans, these findings could indicate that this exposure might favour the pathogenesis of disorders such as ADHD in the further course of animal development. However, this remains uncertain and requires further research [22]. In the elevated plus maze test, mice prenatally exposed to +Nic and -Nic e-liquid travelled a significantly longer distance than the control group [21]. The same effect was also noted in adolescent mice [51]. The Elevated Plus Maze test comprises a box with four passageways which, from a bird's eye view, resembles a plus sign. Half of the passageways are walled in, while the other half is floor only. Crucial for testing anxiety behaviour is that longer stays in the open passageways and travelling a longer distance is interpreted as low anxiety behaviour [32]. Another study confirmed these outcomes. Mice prenatally exposed to both +Nic and -Nic e-liquid stayed longer in the passageways. This behaviour may be interpreted that prenatal e-cigarette exposure decreases anxiety behaviour in mice regardless of nicotine content [29]. A significantly longer stay in the open passageways was found in adolescent animals with prenatal +Nic exposure to e-liquid [51]. The same effect was noted in mice whose mothers were switched from traditional tobacco to +Nic e-liquid exposure from fertilisation onwards [21]. The findings of Nguyen et al., 2019, and Smith et al., 2015, thus indicate that offspring prenatally exposed to typical e-cigarette aerosols with or without nicotine are more active, less anxious and more likely to explore different environ- 
- Table 3 Animal studies on the effects of prenatal e-cigarette exposure on birth parameters.

\begin{tabular}{|c|c|c|c|c|c|c|c|}
\hline $\begin{array}{l}\text { Author, } \\
\text { year } \\
\text { (region) }\end{array}$ & $\begin{array}{l}\text { Study } \\
\text { type }\end{array}$ & $\mathbf{N}$ & $\begin{array}{l}\text { Active } \\
\text { substance }\end{array}$ & Period of exposure & $\begin{array}{l}\text { Measurement } \\
\text { timing }\end{array}$ & Measurements & Outcomes \\
\hline $\begin{array}{l}\text { Church } \\
\text { et al., } 2020 \\
\text { (USA) }\end{array}$ & $\begin{array}{l}\text { Animal } \\
\text { study } \\
\text { (mice) }\end{array}$ & 135 pups & $\begin{array}{l}\text { E-liquid with } \\
\text { and without } \\
\text { nicotine } \\
(16 \mathrm{mg} / \mathrm{mL})\end{array}$ & $\begin{array}{l}\text { Fertilisation to DP } \\
17\end{array}$ & $\begin{array}{l}\text { PN day 21, } 56 \\
\text { and } 84\end{array}$ & $\begin{array}{l}\text { Effects on birth } \\
\text { parameters }\end{array}$ & $\begin{array}{l}\text { No effects on litter size } \\
\text { and birth weight }\end{array}$ \\
\hline $\begin{array}{l}\text { Nguyen } \\
\text { et al., } 2019 \\
\text { (Australia) }\end{array}$ & $\begin{array}{l}\text { Animal } \\
\text { study } \\
\text { (mice) }\end{array}$ & 24 mothers & $\begin{array}{l}\text { Tobacco- } \\
\text { flavoured } \\
\text { e-liquid with } \\
18 \mathrm{mg} / \mathrm{mL} \\
\text { nicotine }\end{array}$ & $\begin{array}{l}\text { TC9 weeks before } \\
\text { fertilisation, } \\
\text { e-liquid until PN } \\
\text { day } 20\end{array}$ & $\begin{array}{l}\text { PN day } 1,20, \\
84 \text { and } 91\end{array}$ & $\begin{array}{l}\text { Effects on birth } \\
\text { parameters }\end{array}$ & $\begin{array}{l}\text { No effects on litter size, } \\
\text { survivability. Reduced } \\
\text { birth weight. }\end{array}$ \\
\hline $\begin{array}{l}\text { Nöel et al., } \\
2020 \text { (USA) }\end{array}$ & $\begin{array}{l}\text { Animal } \\
\text { study } \\
\text { (mice) }\end{array}$ & 183 pups & $\begin{array}{l}\text { Cinnamon- } \\
\text { flavoured } \\
\text { e-liquid with } \\
36 \mathrm{mg} / \mathrm{mL} \\
\text { nicotine }\end{array}$ & $\begin{array}{l}\text { Group A: } 12 \text { days } \\
\text { before fertilisation } \\
\text { until DP } 19 \text { of Group } \\
\text { B: Fertilisation until } \\
\text { DP } 19\end{array}$ & $\begin{array}{l}\text { PN day } 1 \text { und } \\
28\end{array}$ & $\begin{array}{l}\text { Effects on birth } \\
\text { parameters }\end{array}$ & $\begin{array}{l}\text { no effect on litter size, } \\
\text { +Nic e-liquid resulted in } \\
\text { reduced body size and } \\
\text { birth weight }\end{array}$ \\
\hline $\begin{array}{l}\text { Sifat et al., } \\
2020 \text { (USA) }\end{array}$ & $\begin{array}{l}\text { Animal } \\
\text { study } \\
\text { (mice) }\end{array}$ & 121 pups & $\begin{array}{l}\text { E-liquid with } \\
24 \mathrm{mg} / \mathrm{mL} \\
\text { nicotine }\end{array}$ & DP 5 to PN day 7 & $\begin{array}{l}\text { PN day } 8-9 \text { and } \\
40-45\end{array}$ & $\begin{array}{l}\text { Effects on birth } \\
\text { parameters }\end{array}$ & $\begin{array}{l}\text { no effect on litter size, } \\
\text { +Nic e-liquid resulted in } \\
\text { reduced birth weight }\end{array}$ \\
\hline $\begin{array}{l}\text { Palpant } \\
\text { et al., } 2015 \\
\text { (USA) }\end{array}$ & $\begin{array}{l}\text { Animal } \\
\text { study } \\
\text { (zebrafish) }\end{array}$ & n.s. & +Nic e-liquid & 3 days prenatal & PN day $1-3$ & $\begin{array}{l}\text { Effects on birth } \\
\text { parameters }\end{array}$ & $\begin{array}{l}\text { +Nic e-liquid reduced } \\
\text { neonatal survivability }\end{array}$ \\
\hline $\begin{array}{l}\text { Nguyen } \\
\text { et al., } 2018 \\
\text { (Australia) }\end{array}$ & $\begin{array}{l}\text { Animal } \\
\text { study } \\
\text { (mice) }\end{array}$ & 24 mothers & $\begin{array}{l}\text { E-liquid with } \\
\text { and without } \\
\text { nicotine } \\
(18 \mathrm{mg} / \mathrm{mL})\end{array}$ & $\begin{array}{l}6 \text { weeks before } \\
\text { fertilisation until PN } \\
\text { day } 20\end{array}$ & $\begin{array}{l}\text { PN day } 1,20 \\
\text { and } 84\end{array}$ & $\begin{array}{l}\text { Effects on birth } \\
\text { parameters }\end{array}$ & $\begin{array}{l}\text { E-cigarette vaping with- } \\
\text { out effects on weight } \\
\text { and mortality }\end{array}$ \\
\hline $\begin{array}{l}\text { Chen et al., } \\
2017 \\
\text { (Australia) }\end{array}$ & $\begin{array}{l}\text { Animal } \\
\text { study } \\
\text { (mice) }\end{array}$ & n.s. & $\begin{array}{l}\text { E-liquid with } \\
\text { and without } \\
\text { nicotine } \\
(18 \mathrm{mg} / \mathrm{mL})\end{array}$ & $\begin{array}{l}6 \text { weeks before } \\
\text { fertilisation until PN } \\
\text { day } 20\end{array}$ & $\begin{array}{l}\text { PN day } 1,20, \\
91\end{array}$ & $\begin{array}{l}\text { Effects on birth } \\
\text { parameters }\end{array}$ & $\begin{array}{l}\text { No effects on birth } \\
\text { weight and organ } \\
\text { weight, change in fat } \\
\text { distribution. }\end{array}$ \\
\hline $\begin{array}{l}\text { Chen et al., } \\
2018 \\
\text { (Australia) }\end{array}$ & $\begin{array}{l}\text { Animal } \\
\text { study } \\
\text { (mice) }\end{array}$ & 8 mothers & $\begin{array}{l}\text { Tobacco } \\
\text { flavoured } \\
\text { e-liquid with } \\
\text { and without } \\
\text { nicotine } \\
(18 \mathrm{mg} / \mathrm{mL})\end{array}$ & $\begin{array}{l}6 \text { weeks before } \\
\text { fertilisation until PN } \\
\text { day } 20\end{array}$ & PN day 20 & $\begin{array}{l}\text { Effects on birth } \\
\text { parameters }\end{array}$ & $\begin{array}{l}\text { Change in fat distribu- } \\
\text { tion, no change in birth } \\
\text { weight }\end{array}$ \\
\hline $\begin{array}{l}\text { Lauterstein } \\
\text { et al., } 2016 \\
\text { (USA) }\end{array}$ & $\begin{array}{l}\text { Animal } \\
\text { study } \\
\text { (mice) }\end{array}$ & 36 pups & $\begin{array}{l}\text { E-liquid with } \\
\text { and without } \\
\text { nicotine (13- } \\
16 \mathrm{mg} / \mathrm{mL} \text { ) }\end{array}$ & $\begin{array}{l}\text { Fertilisation to PN } \\
\text { day } 25-27\end{array}$ & PN day $25-31$ & $\begin{array}{l}\text { Effects on birth } \\
\text { parameters }\end{array}$ & $\begin{array}{l}\text { No effects of e-cigarette } \\
\text { vaping were observed. }\end{array}$ \\
\hline $\begin{array}{l}\text { Li et al., } \\
2019 \\
\text { (Australia) }\end{array}$ & $\begin{array}{l}\text { Animal } \\
\text { study } \\
\text { (mice) }\end{array}$ & 143 pups & $\begin{array}{l}\text { E-liquid with } \\
\text { and without } \\
\text { nicotine } \\
(18 \mathrm{mg} / \mathrm{mL})\end{array}$ & $\begin{array}{l}\text { Group A: E-liquid } \\
6 \text { weeks before } \\
\text { fertilisation until PN } \\
\text { day } 20 \\
\text { Group B: TC6 weeks } \\
\text { before fertilisation, } \\
\text { then e-liquid until } \\
\text { PN day } 20\end{array}$ & $\begin{array}{l}\text { PN day } 1, \\
\text { PN day } 20\end{array}$ & $\begin{array}{l}\text { Effects on birth } \\
\text { parameters }\end{array}$ & $\begin{array}{l}\text { E-liquid resulted in low- } \\
\text { ered birth weight and no } \\
\text { changes in renal weight. }\end{array}$ \\
\hline $\begin{array}{l}\text { Smith et al., } \\
2015 \text { (USA) }\end{array}$ & $\begin{array}{l}\text { Animal } \\
\text { study } \\
\text { (mice) }\end{array}$ & 28 pups & $\begin{array}{l}\text { E-liquid with } \\
\text { and without } \\
\text { nicotine } \\
(24 \mathrm{mg} / \mathrm{mL})\end{array}$ & $\begin{array}{l}\text { DP } 15-19 \text { and PN } \\
\text { day } 2-16\end{array}$ & PN day 98 & $\begin{array}{l}\text { Effects on birth } \\
\text { parameters }\end{array}$ & $\begin{array}{l}\text { Lower birth weight } \\
\text { (- Nic e-liquid <+Nic } \\
\text { e-liquid < control group) }\end{array}$ \\
\hline $\begin{array}{l}\text { Orbazal } \\
\text { et al., } 2019 \\
\text { (USA) }\end{array}$ & $\begin{array}{l}\text { Animal } \\
\text { study } \\
\text { (mice) }\end{array}$ & n.s. & $\begin{array}{l}\text { E-liquid with } \\
\text { and without } \\
\text { nicotine } \\
(100 \mathrm{mg} / \mathrm{mL})\end{array}$ & ST 5 - PN10 & PN day 10 & $\begin{array}{l}\text { Effects on birth } \\
\text { parameters }\end{array}$ & $\begin{array}{l}\text { Lowered birth weight } \\
\text { and smaller size with } \\
\text { +Nic e-liquid }\end{array}$ \\
\hline
\end{tabular}

$\mathrm{PN}=$ postnatal day; $\mathrm{DP}=$ day of pregnancy; $\mathrm{TC}=$ traditional cigarettes; $\mathrm{n} . \mathrm{s} .=$ not specified 
- Table 4 Animal studies on the effects of prenatal e-cigarette exposure on cognition and behaviour.

\begin{tabular}{|c|c|c|c|c|c|c|c|}
\hline $\begin{array}{l}\text { Author, } \\
\text { year } \\
\text { (region) }\end{array}$ & $\begin{array}{l}\text { Study } \\
\text { type }\end{array}$ & N & $\begin{array}{l}\text { Active } \\
\text { substance }\end{array}$ & Period of exposure & $\begin{array}{l}\text { Measurement } \\
\text { timing }\end{array}$ & Measurements & Outcomes \\
\hline $\begin{array}{l}\text { Sifat et al., } \\
2020 \text { (USA) }\end{array}$ & $\begin{array}{l}\text { Animal } \\
\text { study } \\
\text { (mice) }\end{array}$ & 121 pups & $\begin{array}{l}\text { E-liquid with } \\
24 \mathrm{mg} / \mathrm{mL} \\
\text { nicotine }\end{array}$ & DP 5 to PN day 7 & $\begin{array}{l}\text { PN day } 8-9 \text { and } \\
40-45\end{array}$ & $\begin{array}{l}\text { Effects on cortical } \\
\text { cells }\end{array}$ & $\begin{array}{l}\text { Deterioration in memo- } \\
\text { ry, learning, motor } \\
\text { coordination. } \\
\text { Reduced cellular vitality. }\end{array}$ \\
\hline $\begin{array}{l}\text { Nguyen } \\
\text { et al., } 2018 \\
\text { (Australia) }\end{array}$ & $\begin{array}{l}\text { Animal } \\
\text { study } \\
\text { (mice) }\end{array}$ & 24 mothers & $\begin{array}{l}\text { E-liquid with } \\
\text { and without } \\
\text { nicotine } \\
(18 \mathrm{mg} / \mathrm{mL})\end{array}$ & $\begin{array}{l}6 \text { weeks before } \\
\text { fertilisation until PN } \\
\text { day } 20\end{array}$ & $\begin{array}{l}\text { PN day } 1,20 \\
\text { and } 84\end{array}$ & $\begin{array}{l}\text { Cognitive and } \\
\text { neuroepigenetic } \\
\text { changes }\end{array}$ & $\begin{array}{l}\text { Increased curiosity } \\
\text { behaviour. Decreased } \\
\text { object recognition. }\end{array}$ \\
\hline $\begin{array}{l}\text { Nguyen } \\
\text { et al., } 2019 \\
\text { (Australia) }\end{array}$ & $\begin{array}{l}\text { Animal } \\
\text { study } \\
\text { (mice) }\end{array}$ & 24 mothers & $\begin{array}{l}\text { Tobacco- } \\
\text { flavoured } \\
\text { e-liquid with } \\
18 \mathrm{mg} / \mathrm{mL} \\
\text { nicotine }\end{array}$ & $\begin{array}{l}\text { Group A: TC9 weeks } \\
\text { before fertilisation, } \\
\text { e-liquid until PN } \\
\text { day } 20 \\
\text { Group B: E-liquid } \\
\text { fertilisation until PN } \\
\text { day } 20\end{array}$ & $\begin{array}{l}\text { PN day } 1,20, \\
84 \text { and } 91\end{array}$ & $\begin{array}{l}\text { Effects on memo- } \\
\text { ry and behaviour } \\
\text { and neuroepi- } \\
\text { genetic changes }\end{array}$ & $\begin{array}{l}\text { Increased exploration } \\
\text { behaviour. At times } \\
\text { minor neuroepigenetic } \\
\text { changes and limited } \\
\text { STM. }\end{array}$ \\
\hline $\begin{array}{l}\text { Church } \\
\text { et al., } 2020 \\
\text { (USA) }\end{array}$ & $\begin{array}{l}\text { Animal } \\
\text { study } \\
\text { (mice) }\end{array}$ & 135 pups & $\begin{array}{l}\text { E-liquid with } \\
\text { and without } \\
\text { nicotine } \\
(16 \mathrm{mg} / \mathrm{mL})\end{array}$ & $\begin{array}{l}\text { Fertilisation to DP } \\
17\end{array}$ & $\begin{array}{l}\text { PN day } 21,56 \\
\text { and } 84\end{array}$ & $\begin{array}{l}\text { Effects on cogni- } \\
\text { tion and neuro- } \\
\text { inflammation }\end{array}$ & $\begin{array}{l}\text { Changes in cognitive } \\
\text { abilities. Elevated in- } \\
\text { flammation levels in } \\
\text { individual brain regions }\end{array}$ \\
\hline $\begin{array}{l}\text { Smith et al., } \\
2015 \text { (USA) }\end{array}$ & $\begin{array}{l}\text { Animal } \\
\text { study } \\
\text { (mice) }\end{array}$ & 28 pups & $\begin{array}{l}\text { E-liquid with } \\
\text { and without } \\
\text { nicotine } \\
(24 \mathrm{mg} / \mathrm{mL})\end{array}$ & $\begin{array}{l}\text { DP } 15-19 \text { and PN } \\
\text { day 2-16 }\end{array}$ & PN day 98 & Cognitive effects & $\begin{array}{l}\text { Increased motor activity } \\
\text { and diminished anxiety } \\
\text { behaviour }\end{array}$ \\
\hline
\end{tabular}

ments. The literature also describes other measurements of reduced anxiety in the form of behaviours such as body stretching, standing on the hind paws and head nudging [32,51]. Young animals with prenatal exposure to +Nic e-liquid exhibited more nudging motions of the head [21]. Findings on the presence of body stretching in the Elevated Plus Test differed for open and closed passageways. While movements in the closed passageways were observed just as often in all study groups, animals in the group of prenatal-Nic e-liquid exposure exhibited significantly more movements in the open passageways [21,51]. Findings on the effects regarding anxiety symptoms appear inconclusive in the further course of animal development. Reduced anxiety behaviour, measured by the increased time spent in open versus closed passageways, was measured once again in adolescence after prenatal e-liquid exposure, independent of nicotine content. Following prenatal nicotine exposure, the second reading revealed an increased incidence of exploratory nudging movements of the head. In addition, prenatal -Nic e-liquid exposure promoted body stretching, as did tobacco exposure. With regard to behaviour, the studies listed demonstrated that while it appears to be affected by prenatal e-liquid exposure, these changes were generally independent of the nicotine content.

\section{Discussion}

This review analyses 17 research papers of the last 10 years on the effects of prenatal exposure to e-cigarettes. These papers included research on neurobiological effects $(n=8)$ and research on the effects on the lungs and other organ systems $(n=8)$. Some of the 17 studies overall also provided information on effects on birth parameters $(n=12)$ and on cognition and behaviour $(n=5)$. All research involved animal or in vitro studies. To date, the current literature does not contain any studies on humans.

\section{Comparison with effects of traditional cigarettes}

Due to the lack of studies in humans, definitive comparison of the effects of prenatal exposure to e-cigarettes and conventional cigarettes is limited at present. Present findings on prenatal exposure to e-cigarettes based on in vitro and animal studies cannot be fully translated to the human body and therefore cannot be compared directly with those of traditional cigarettes [52,53]. The small number of studies identified and the lack of studies in humans might be explained by the fact that e-cigarettes have only been available as a commercial product since 2007 and have only gained popularity in the last few years [54]. Most in vitro and animal studies indicate a potential risk to the developing foetus, primarily due to the nicotine consumed $[7,16]$. The latter is a main constituent of the e-cigarette, just as it is with traditional cigarettes. Thus, the adverse effects known from human studies on prenatal exposure to traditional cigarettes and nicotine-containing tobacco products might also be induced by nicotine-containing e-cigarettes.

Nicotine passes through the placental barrier and is thus distributed in the foetal body. As a result, the foetus can only eliminate it slowly, which results in higher exposure [55]. Studies in hu- 
mans have demonstrated that nicotine exposure is a major cause of a wide range of adverse and pathological birth outcomes such as low birth weight, miscarriage and stillbirth $[3,55]$. Moreover, the literature reports a significantly increased risk of sudden infant death syndrome, obesity, type 2 diabetes $[3,56]$, as well as a reduction in male reproductive capacity [57] and earlier menarche in young females [56]. Nicotine consumption during pregnancy affects various physiological parameters in pregnant women, leading to oxygen deficiency in the foetus. Hypoxaemia reduces foetal nutrient supply through nicotine-induced impairment of the uteroplacental blood flow [56]. This may result in a wide range of respiratory disorders such as bronchitis and asthma $[3,56]$. By crossing the placental barrier, nicotine also affects neuronal development via the neurotransmitter system [56]. Due to its close similarity with the neurotransmitter acetylcholine, nicotine is thought to bind to its receptors $[58,59]$. Nicotinic acetylcholine receptors are involved in the development of various neurotransmitter systems that are dysregulated by nicotine use [59]. This may lead to errors in the processing of basic cognitive processes such as learning, memory and attentiveness [60]. Other effects with possible onset at later stages of development include behavioural problems such as lower global intelligence [56] and attention deficit hyperactivity disorder (ADHD). The known effects of nicotine alone clearly show that the consumption of nicotine-containing e-cigarettes is less of an alternative-safe way of giving up traditional cigarettes, but can rather lead to the above sequelae in affected offspring.

In addition to nicotine, tobacco smoke from traditional cigarettes also contains numerous other harmful substances. About 40 of these are foetotoxic, including tar and carbon monoxide [61]. Compared to traditional cigarettes, electronic nicotine delivery systems are non-flammable and are believed to contain correspondingly fewer toxins such as carbon monoxide [62]. However, in addition to the nicotine content, other substances in the e-cigarette and their mode of action must also be taken into account. Many studies on the effects of prenatal e-cigarette exposure on the foetus only refer to the effects of pure nicotine and not to the e-cigarette aerosol in its entirety. Nevertheless, there is also evidence of sequelae that are not due to nicotine but to other components of e-cigarettes, such as flavours and substrates [22, 48]. In addition to nicotine, the e-cigarette liquids to be consumed contain substrates such as propylene glycol and glycerine as well as various flavours. Propylene glycol and glycerine are sweet tasting colourless viscous liquids. The effects caused by the inhalation of these substrates are still unknown, which is why a negative effect cannot be ruled out. Some of the flavoured "juices" can also be even more irritating to the lungs than the substances in traditional cigarettes. Moreover, flavours appear to have different effects. This was shown in studies of the lung tissue of affected offspring, where menthol and strawberry flavouring, but not tobacco or vanilla flavouring, increased cell death [40]. Cherry flavouring seems to be the most harmful, as it contains benzaldehydes that have a foetotoxic effect [63]. Previous findings still need to be supplemented by further research based on studies in humans. However, the assumption that e-cigarettes can be classified as a safer alternative to conventional cigarettes can be ruled out.

\section{Methodological limitations}

This review has some limitations with regard to current research results. Studies on the effects of prenatal e-cigarette exposure show methodological heterogeneity with regard to certain aspects. For example, animals are exposed to the e-cigarette liquid for different lengths of time. This varies the intensity of the exposure, which has a corresponding effect on the scale of the effects observed in the offspring. In addition, there has been inadequate research into the substrates and flavours of e-cigarette liquids. While substance comparison between e-cigarette liquid and traditional cigarettes is primarily based on nicotine, there is a lack of studies on the effects of substrates and various flavours. The literature to date already suggests that there may be negative effects arising from the substrates and flavours [22, 40,48]. However, little is known about this yet.

Moreover, the current literature is clearly lacking studies on humans. Due to still inadequately documented prevalences of e-cigarette vaping in general and during pregnancy, a consistent, global comparison is not possible. This complicates adequate prevention approaches concerning relevant target groups. Furthermore, no clear conclusions can yet be drawn about the effects of prenatal e-cigarette exposure on affected offspring.

The translation of conclusions from animal studies to the human body and between different animal species is still under discussion. With their similar evolutionary development, mice and apes resemble humans [52]. Moreover, mice have the same organs and similar functions of their circulatory, reproductive, digestive, hormonal, and nervous systems as humans. Due to these similarities, mice in particular can develop diseases that very closely resemble the equivalent clinical picture in humans. Thus, parts of the outcomes from mouse models can be translated to humans [53]. In the context of animal studies, it is possible to work experimentally in a variety of ways, but it is still important to aim for studies on the effects of e-cigarettes on early development in humans. The lack of studies in humans to date may be related to the fact that cigarette vaping is not yet widely seen as an unsafe and potentially harmful alternative to traditional cigarettes, and that this approach is advocated by medical experts.

With regard to e-cigarette exposure in particular, the animal studies also suffer from methodological limitations. Unlike humans, laboratory animals are exposed to passive consumption of the e-cigarette aerosol while they are in a designated apparatus. During nasal inhalation, the animals inhale additional air particles that can affect the findings. Although the significance of this has not been adequately studied, it seems to be a methodological disadvantage of animal studies compared to studies in humans [32]. Another aspect to be considered in animal studies is that the development of the brain differs from that in the human body. In the human foetus, the developmental phase is completed in the third trimester, while in mice it continues into the postnatal period. Translated to the human body, the outcomes of animal studies on early postnatal phases are thus still the prenatal period in humans [32].

\section{Implications for future research and clinical practice}

An increasingly harmonised methodological approach with, for example, coherent e-liquid exposure periods could lead to better 
inter-study comparisons. In animal model studies in particular, methodological approaches can be standardised, as exposure times and media can be applied uniformly. In human samples, however, this is limited. For future research, attention could be paid here to uniformly determine prevalences of e-cigarette vaping, as well as effects on affected offspring. Determination of the exact prevalences would require uniform definitions of vaping quantities such as small, moderate or large quantities and, at best, biomarker level measurements of the toxic substances. As in recent studies by Schilling et al [5], the risk assessment of e-cigarette use could be examined by questionnaires. This could contribute to the formulation of adequate preventive measures.

It is also vital that the present findings of in vitro and animal studies be corroborated by studies in humans. This would simplify the comparison with traditional cigarettes regarding the effects on human offspring, and the effects of e-cigarette exposure could thus be more clearly assessed in the research context.

The current literature primarily depicts negative effects of nicotine as a component of e-cigarettes (e.g. [23]). Due to the additional substrates and flavours, further research into their effects would also be essential. This is particularly important for adequate risk assessment of e-cigarette vaping during pregnancy.

In clinical practice, preventive information should be provided on the basis of current research findings about the numerous possible sequelae. During risk assessment and corresponding counselling of pregnant women, parallels to traditional cigarettes can also be pointed out, which are already known to be a foetotoxic substance with regard to nicotine. Here, it could be made clear that e-cigarettes can no longer be vaped as the safe alternative originally claimed, but rather that this has already been disproved by current research outcomes. This could be supported by drawing attention to the fact that health-related institutions such as the WHO also recommend against e-cigarette vaping during pregnancy. It should also be made clear that vaping should be discontinued if pregnancy is planned or possible, in order to avoid early abortions and sequelae in affected offspring. This could be provided within the framework of gynaecological and pregnancy screening by midwives and gynaecologists, as well as in the practice of other specialties in social and medical care.

\section{Conclusion}

Analysis of the current state of research highlights that a variety of effects of e-cigarettes and their ingredients on foetal development are known. However, outcomes to date are based solely on in vitro and animal studies, which cannot be translated in toto to humans. Studies in humans should be pursued in order to establish well-founded conclusions for the human body. In addition to a coherent methodological inter-study approach, future research on the substrates and flavours contained in the liquid of e-cigarettes should be pursued in order to identify their mode of action. There are already findings confirming that prenatal exposure to substrates and flavours without nicotine is harmful. Based on existing reviews in combination with the research outcomes, it can be concluded that prenatal exposure to e-cigarettes has a negative multifaceted impact. This paper complements previous reviews by providing a German-language version that addresses a broad spectrum of relevant healthcare professionals. So far, e-cigarette vaping and its consequences have not been part of pregnancy counselling. It is essential to provide more informed advice on current outcomes to healthcare professionals involved in supporting pregnant women, including midwives, psychologists and physicians. Such information should be shared with society in general. This can ensure that pregnant women receive comprehensive advice on e-cigarette vaping and its potential risks.

\section{Acknowledgements}

The project on which this review is based is funded by the German Federal Ministry of Education and Research under grant number 01NV1601C. The responsibility for the content of this publication lies with the authors. The project is co-financed by the City of Bremen and the Jacobs Foundation.

We would like to express our gratitude to Prof. Dr. Michael Koch for important comments on the manuscript.

\section{Conflict of Interest}

The authors declare that they have no conflict of interest.

\section{References}

[1] Boseley S. Hon Lik invented the e-cigarette to quit smoking - but now he's a dual user. The Guardian 2015. Accessed December 01, 2020 at: https://www.theguardian.com/society/2015/jun/09/hon-lik-ecigarette-inventor-quit-smoking-dual-user

[2] Schupp JC, Prasse A, Erythropel HC. E-Cigarettes - Operating Principle, Ingredients, and Associated Acute Lung Injury | E-Zigaretten - Funktionsweise, Inhaltsstoffe und die Vaping-assoziierte akute Lungenschädigung. Pneumologie 2020; 74: 77-87. doi:10.1055/a-1078-8126

[3] Mendelsohn C, Gould GS, Oncken C. Management of smoking in pregnant women. Aust Fam Physician 2014; 43: 46-51

[4] Directorate-General for Health and Food safety. Special Eurobarometer 506 Report Attitudes of Europeans towards tobacco and electronic cigarettes February 2021 Survey requested by the European Commission. 2021. Accessed February 03, 2021 at: https://europa.eu/ eurobarometer/surveys/detail/2240

[5] Schilling L, Schneider S, Maul H et al. STudy on E-Cigarettes and Pregnancy (STEP) - Study Protocol of a Mixed Methods Study on Risk Perception of E-Cigarette Use During Pregnancy and Sample Description. Geburtshilfe Frauenheilkd 2020; 80: 66-75

[6] Wagner N], Camerota M, Propper C. Prevalence and Perceptions of Electronic Cigarette Use during Pregnancy. Matern Child Health J 2017; 21: 1655-1661. doi:10.1007/s10995-016-2257-9

[7] Whittington JR, Simmons PM, Phillips AM et al. The Use of Electronic Cigarettes in Pregnancy: A Review of the Literature. Obs Gynecol Surv 2018; 73: 544-549. doi:10.1097/OGX.00000000000000595

[8] Bhandari NR, Day KD, Payakachat $N$ et al. Use and Risk Perception of Electronic Nicotine Delivery Systems and Tobacco in Pregnancy. Womens Health Issues 2018. doi:10.1016/j.whi.2018.02.005

[9] Chiang SC, Abroms LC, Cleary SD et al. E-cigarettes and smoking cessation: a prospective study of a national sample of pregnant smokers. BMC Public Health 2019; 19: 964. doi:10.1186/s12889-019-7299-7

[10] Lange S, Probst C, Rehm J et al. National, regional, and global prevalence of smoking during pregnancy in the general population: a systematic review and meta-analysis. Lancet Glob Heal 2018; 6: e769-e776. doi:10.1016/S2214-109X(18)30223-7 
[11] Kahr MK, Padgett S, Shope CD et al. A qualitative assessment of the perceived risks of electronic cigarette and hookah use in pregnancy. BMC Public Health 2015; 15: 1-8. doi:10.1186/s12889-015-2586-4

[12] NHS. Stop smoking in pregnancy-Your pregnancy and baby guide. 2020. Accessed December 16, 2020 at: https://www.nhs.uk/conditions/ pregnancy-and-baby/smoking-pregnant

[13] Stratton K, Kwan LY, Eaton DL. Public Health Consequences of E-Cigarettes. Washington, D.C.: National Academies Press (US); 2018. doi:10.17226/24836

[14] Nulman I, Shulman T, Liu F. Fetal Alcohol Spectrum Disorder. In: Slikker W jr., Paule MG, Wang C, eds. Handbook of developmental Neurotoxicology. London: Academic Press; 2018: 427-437. doi:10.1016/B978-0-12809405-1.00038-9

[15] World Health Organization. WHO recommendations for the prevention and management of tobacco use and second-hand smoke exposure in pregnancy. World Heal Organ 2013; ISBN: 9789241506076 . Accessed December 16, 2020 at: https://apps.who.int/iris/handle/10665/94555

[16] Peterson LA, Hecht SS. Tobacco, e-cigarettes, and child health. Curr Opin Pediatr 2017; 29: 225-230. doi:10.1097/MOP.0000000000000456

[17] Lødrup Carlsen KC, Skjerven HO, Carlsen KH. The toxicity of E-cigarettes and children's respiratory health. Paediatr Respir Rev 2018; 28: 63-67. doi:10.1016/j.prrv.2018.01.002

[18] McCubbin A, Fallin-Bennett A, Barnett J et al. Perceptions and use of electronic cigarettes in pregnancy. Health Educ Res 2017; 32: 22-32. doi:10.1093/her/cyw059

[19] National Toxicology Program. OHAT Risk of Bias Rating Tool for Human and Animal Studies. Off Heal Assess Transl 2015. Accessed November 06, 2020 at: https://ntp.niehs.nih.gov/ntp/ohat/pubs/riskofbiastool_ 508.pdf

[20] Viswanathan M, Berkman ND, Dryden DM et al. Assessing risk of bias and confounding in observational studies of interventions or exposures: further development of the RTI item bank. Methods Res Rep 2013 (Prepared by RTI-UNC Evidence-based Practice Center under Contract No. 290-2007-10056-I). AHRQ Publication No. 13-EHC106-EF. Rockville, MD: Agency for Healthcare Research and Quality. Accessed November 06, 2020 at: www.effectivehealthcare.ahrq.gov/reports/final.cfm

[21] Nguyen T, Li GE, Chen $\mathrm{H}$ et al. Neurological Effects in the Offspring after Switching from Tobacco Cigarettes to E-Cigarettes during Pregnancy in a Mouse Model. Toxicol Sci 2019; 172: 191-200. doi:10.1093/toxsci/ kfz194

[22] Sifat AE, Nozohouri S, Villalba H et al. Prenatal electronic cigarette exposure decreases brain glucose utilization and worsens outcome in offspring hypoxic-ischemic brain injury. J Neurochem 2020; 153: 63-79. doi:10.1111/jnc. 14947

[23] Zahedi A, Phandthong R, Chaili A et al. Mitochondrial Stress Response in Neural Stem Cells Exposed to Electronic Cigarettes. iScience 2019; 16: 250-269. doi:10.1016/j.isci.2019.05.034

[24] Schiebler T, Korf H, Hrsg. Anatomie. 9. Aufl. Darmstadt: Steinkopff Verlag; 2007

[25] Das R, Chakrabarti O. Mitochondrial hyperfusion: a friend or a foe. Biochem Soc Trans 2020; 48: 631-644

[26] Müller-Esterl W, Hrsg. Biochemie. 2. Aufl. Heidelberg: Spektrum, Akademischer Verlag; 2011

[27] Rassow J, Hauser K, Netzker R, Deutzmann R, Hrsg. Biochemie. Duale Reihe. 4. Aufl. Stuttgart: Thieme; 2016

[28] Strachan T, Read A, Seidler L, Hrsg. Molekulare Humangenetik. 3. Aufl. Heidelberg: Elsevier/Spektrum Akademischer Verl.; 2005

[29] Nguyen T, Li GE, Chen H et al. Maternal E-Cigarette Exposure Results in Cognitive and Epigenetic Alterations in Offspring in a Mouse Model. Chem Res Toxicol 2018; 31: 601-611. doi:10.1165/rcmb.2017-0206RC
[30] Lauterstein DE, Tijerina PB, Corbett K et al. Frontal cortex transcriptome analysis of mice exposed to electronic cigarettes during early life stages. Int J Environ Res Public Health 2016; 13: 1-14. doi:10.3390/ ijerph13040417

[31] DiSabato D, Quan N, Godbout JP. Neuroinflammation: The devil is in the details. J Neurochem 2016; 139: 136-153. doi:10.1016/j.jtcvs.2018. 03.025

[32] Church JS, Chace-Donahue F, Blum JL et al. Neuroinflammatory and Behavioral Outcomes Measured in Adult Offspring of Mice Exposed Prenatally to E-cigarette Aerosols. Environ Health Perspect 2020. doi:10.1289/ EHP6067

[33] Piao WH, Campagnolo D, Dayao C et al. Nicotine and inflammatory neurological disorders. Acta Pharmacol Sin 2009; 30: 715-722. doi:10.1038/aps.2009.67

[34] Zelikoff JT, Parmalee NL, Corbett K et al. Microglia activation and gene expression alteration of neurotrophins in the hippocampus following early-life exposure to E-cigarette aerosols in a murine model. Toxicol Sci 2018; 162: 276-286. doi:10.1093/TOXSCI/KFX257

[35] Chen H, Li G, Chan YL et al. Modulation of neural regulators of energy homeostasis, and of inflammation, in the pups of mice exposed to e-cigarettes. Neurosci Lett 2018; 684: 61-66

[36] Chen H, Saad S, Sandow SL et al. Cigarette smoking and brain regulation of energy homeostasis. Front Pharmacol 2012. doi:10.3389/fphar.2012. 00147

[37] Noël A, Hansen S, Zaman A et al. In utero exposures to electronic-cigarette aerosols impair the Wnt signaling during mouse lung development. Am J Physiol Lung Cell Mol Physiol 2020; 318: L705-L722. doi:10.1152/ajplung.00408.2019

[38] Speckmann E-J, Heschler J, Köhling R, Hrsg. Physiologie. 5. Aufl. München: Elsevier; 2008

[39] Chen H, Li G, Chan YL et al. Maternal E-Cigarette Exposure in Mice Alters DNA Methylation and Lung Cytokine Expression in Offspring. Am J Respir Cell Mol Biol 2017; 58: 366-377. doi:10.1165/rcmb.2017-0206RC

[40] Berkelhamer SK, Helman JM, Gugino SF et al. In Vitro Consequences of Electronic-Cigarette Flavoring Exposure on the Immature Lung. Int J Environ Res Public Health 2019; 16: 3635

[41] Ahijevych K, Garrett BE. Menthol pharmacology and its potential impact on cigarette smoking behavior. Nicotine Tob Res 2004. doi:10.1080/ 14622200310001649469

[42] McAlinden KD, Chan YL, Kota A et al. Maternal E-Cigarette Vaping Enhances Developing of Allergic Asthma in the Offspring. Am J Respir Crit Care Med Abstr 2017; 1: 195

[43] Orbazal MR, Lunde-Young ER, Ramirez Jl et al. Chronic Exposure to E-Cig Aerosols during Early Development Causes Dysfunction and Offspring Growth Deficits. Transl Res 2019; 207: 70-82. doi:10.1016/ j.physbeh.2017.03.040

[44] Palpant NJ, Hofsteen P, Pabon L et al. Cardiac Development in Zebrafish and Human Embryonic Stem Cells Is Inhibited by Exposure to Tobacco Cigarettes and E-Cigarettes. PLoS One 2015; 10: e0126259

[45] Greten H, Andrassy K, Hrsg. Innere Medizin. Stuttgart: Thieme; 2005

[46] Palpant NJ, Hofsteen P, Pabon L et al. Cardiac development in zebrafish and human embryonic stem cells is inhibited by exposure to tobacco cigarettes and e-cigarettes. PLoS One 2015; 10: e0126259. doi:10.1371/ journal.pone.0126259

[47] Rohen J, Lütjen-Drecoll E. Funktionelle Embryologie. 3. Aufl. Stuttgart: Schattauer; 2006

[48] Li G, Chan YL, Nguyen LT et al. Impact of maternal e-cigarette vapor exposure on renal health in the offspring. Ann N Y Acad Sci 2019; 1452: 65-77. doi:10.1111/nyas. 14174

[49] Kennedy AE, Kandalam S, Olivares-Navarrete R et al. E-cigarette aerosol exposure can cause craniofacial defects in Xenopus laevis embryos and mammalian neural crest cells. PLoS One 2017; 12: e0185729. doi:10.1371/journal.pone.0185729 
[50] Altintas MM, Rossetti MA, Nayer B et al. Apoptosis, mastocytosis, and diminished adipocytokine gene expression accompany reduced epididymal fat mass in long-standing diet-induced obese mice. Lipids Health Dis 2011; 10: 1-12. doi:10.1186/1476-511X-10-198

[51] Smith D, Aherrera A, Lopez A et al. Adult behavior in male mice exposed to E-cigarette nicotine vapors during late prenatal and early postnatal life. PLoS One 2015; 10: e0137953. doi:10.1371/journal.pone.0137953

[52] Max-Planck-Institut. Where is animal research carried out in Germany? 2020. Accessed December 16, 2020 at: https://www.mpg.de/animalstudies-in-basic-research

[53] Jackson Laboratories. Why are mice considered exellent models for humans? 2020. Accessed December 16, 2020 at: https://www.jax.org/ why-the-mouse/exellent-models

[54] Polosa R, Caponnetto P, Morjaria JB et al. Impact of an electronic cigarette on smoking reduction and cessation in schizophrenic smokers: A prospective 12-month pilot study. Int ] Environ Res Public Health 2013; 10: 446-461. doi:10.3390/ijerph10020446

[55] Katsaounou PA, Papadakis S. Reply to Letter to the Editor on 'Smoking cessation in pregnancy: An update for maternity care practitioners'. Tob Induc Dis 2020; 18: 24. doi:10.18332/tid/118164

[56] Holbrook BD. The effects of nicotine on human fetal development. Birth Defects Res C Embryo Today 2016; 108: 181-192. doi:10.1002/ bdrc. 21128
[57] Fowler PA, Bhattacharya S, Flannigan S et al. Maternal cigarette smoking and effects on androgen action in male offspring: Unexpected effects on second-trimester anogenital distance. J Clin Endocrinol Metab 2011; 96: 1502-1506. doi:10.1210/jc.2011-1100

[58] Tiesler CMT, Heinrich J. Prenatal nicotine exposure and child behavioural problems. Eur Child Adolesc Psychiatry 2014; 23: 913-929. doi:10.1007/s00787-014-0615-y

[59] Dwyer JB, McQuown SC, Leslie FM. The dynamic effects of nicotine on the developing brain. Pharmacol Ther 2009; 122: 125-139. doi:10.1016/j.pharmthera.2009.02.003

[60] Bublitz MH, Stroud LR. Maternal smoking during pregnancy and offspring brain structure and function: review and agenda for future research. Nicotine Tob Res 2011; 14: 388-397

[61] Benowitz NL, Hukkanen J, Jacob P. Nicotine Chemistry, Metabolism, Kinetics and Biomarkers. Bone 2008; 23: 1-7. doi:10.1007/978-3-54069248-5

[62] Aubard Y. Carbon Monoxide Poisoning in Pregnancy. Am J Obstet Gynecol 1965; 92: 526-528. doi:10.1016/50002-9378(16)34845-1

[63] Kosmider L, Sobczak A, Prokopowicz A et al. Cherry-flavoured electronic cigarettes expose users to the inhalation irritant, Benzaldehyde. Thorax 2016; 71: 376-377. doi:10.1136/thoraxjnl-2015-207895 